\title{
Seroprevalence of herpes simplex virus type 1 among people living with HIV in Mbeya, Tanzania
}

Habakkuk Mwakyula Issakwisa, ${ }^{1,2^{*}}$, Gloria Reginald Mbwile ${ }^{2,3}$, Godlove Fred Mbwanji, ${ }^{1,2}$, David Daniel Nassoro ${ }^{1,2}$, Nyanda Elias Ntinginya ${ }^{4}$ and Anthony Ambikile Nsojo $0^{1,2}$

\begin{abstract}
Background: Despite the significant decline in the prevalence of HIV in Tanzania, the prevalence rates in Mbeya, Iringa, and Njombe regions are higher than the national average and have remained stable for years. The current stable HIV prevalence may be driven by factors such as a high incidence of sexually transmitted infections (STIs) and high-risk behaviours. In sub-Saharan Africa, it has previously been observed that up to 50\% of HIV cases were attributed to herpes simplex type 2 (HSV-2) among low-risk populations. Because the proportion of sexually transmitted HSV-1 is rising, it is essential to study the interaction between HSV-1 and HIV infections.

Methods: We conducted a study in Mbeya region using the archived blood sera of participants from the recently completed EU-funded EMINI project. A specially designed questionnaire was used to obtain the social and demographic characteristics of the study participants in the database. We tested archived participants' sera for herpes simplex virus type 1 using Virotech HSV-1 (gG1) IgG ELISA (Enzygnost, Behring, Germany). Univariate and multivariate Poisson regression models were used to identify factors associated with HSV-1.

Results: A total of 640 adults were randomly recruited after stratification by HIV status ( 318 were HIV positive), age, and sex. The overall seroprevalence of HSV-1 in the study population was $92.1 \%$. The extrapolated seroprevalence estimate of herpes simplex virus type 1 in the general population was $95.0 \%$ (96.0\% in males versus $94.0 \%$ in females). Males and females were equally affected by HSV-1. HSV-1 was less prevalent in HIV-positive individuals than in HIV-negative individuals.
\end{abstract}

Conclusion: People living with HIV were less likely to be HSV-1 seropositive. Further prospective studies are necessary to conclude a causal association.

Keywords: Prevalence, HSV-1, Human Immunodeficiency Virus, Mwakyula

\footnotetext{
* Correspondence: ozzanne@gmail.com

${ }^{1}$ Mbeya Zonal Referral Hospital, Mbeya, Tanzania

${ }^{2}$ University of Dar es Salaam Mbeya College of Health and Allied Sciences,

Mbeya, Tanzania

Full list of author information is available at the end of the article
}

(c) The Author(s). 2020 Open Access This article is licensed under a Creative Commons Attribution 4.0 International License, which permits use, sharing, adaptation, distribution and reproduction in any medium or format, as long as you give appropriate credit to the original author(s) and the source, provide a link to the Creative Commons licence, and indicate if changes were made. The images or other third party material in this article are included in the article's Creative Commons licence, unless indicated otherwise in a credit line to the material. If material is not included in the article's Creative Commons licence and your intended use is not permitted by statutory regulation or exceeds the permitted use, you will need to obtain permission directly from the copyright holder. To view a copy of this licence, visit http://creativecommons.org/licenses/by/4.0/ The Creative Commons Public Domain Dedication waiver (http://creativecommons.org/publicdomain/zero/1.0/) applies to the data made available in this article, unless otherwise stated in a credit line to the data. 


\section{Background}

In mainland Tanzania, the prevalence of human immunodeficiency virus (HIV) infection among adults aged 15-49 years is $4.7 \%$, and the prevalence among females is twice that among males $(6.2 \%$ vs. $3.1 \%)$. Although there is evidence of a significant decline in the prevalence of HIV in Tanzania, the prevalence rates in Mbeya, Iringa, and Njombe regions $(9.3,11.3$, and $11.4 \%$ respectively) are higher than the national average and are stable [1].

The current stable HIV prevalence may be driven by a high incidence of sexually transmitted infections (STIs) and high-risk behaviours among patients in sub-Saharan Africa who are taking antiretroviral therapy (ART) $[2,3]$. In contrast, individuals undergoing ART in northern Africa tend to adopt protective behaviours more frequently than those who are not undergoing treatment [4].

Herpes simplex virus type 1 (HSV-1) predominantly causes orolabial ulcers and is acquired during childhood, while HSV-2 causes genital herpes that is commonly associated with sexual activities. Sufficient evidence has demonstrated an increase in HSV-1 anogenital isolates [5-10].

There is some evidence that a large proportion of HIV infections is attributable to HSV-2 [11, 12]. In subSaharan Africa, it has previously been observed that among low-risk populations, $25 \%$ [13] to 50\% [14] of HIV-1 cases were attributable to HSV-2. HSV-2 disrupts the epithelial barrier and recruits immune cells, which are targets for HIV in the genital area, thereby facilitating the entry of HIV [15].

Since the proportion of sexually transmitted HSV-1 is rising and HSV-1 leads to the persistent shedding of oropharyngeal mucosal ulcers and ulcerations of genital mucosa and skin [16], it is essential to study the potential role of HSV-1 as a risk factor for HIV infection.

\section{Methods}

The current study was a population-based crosssectional study that analysed data and blood from a subset of participants who were recruited into the EMINI (Establishment of the Infrastructure to Evaluate and Monitor the Impact of New Interventions) cohort.

EMINI was a population-based cohort study that was conducted in Mbeya region between May 2005 and 2009. It included 20,000 people enrolled from $10 \%$ of all households in nine randomly selected communities (urban, semi-urban, and rural). The overall objective of the EMINI project was to contribute to the general improvement of health by controlling communicable diseases in Mbeya region.

During each of the annual study visits, a research team visited every participant to conduct a general physical examination, perform interviews (particularly about sexual risk behaviours), and collect several specimens, including blood samples.
The blood specimens collected from the participants were then tested for HIV-1 in the NIMR-MMRC central laboratory at the Mbeya Zonal Referral Hospital in accordance with the existing national HIV testing algorithm. During each survey, serum from every participant was stored at $-80{ }^{\circ} \mathrm{C}$ for future use.

The HSV-1-specific gG1 IgG assay (Enzygnost, Behring, Marburg, Germany) was used to examine samples for HSV-1. This assay is an ELISA for the semiquantitative and qualitative detection of IgG antibodies against HSV-1 in human serum. Standard operating procedures and data worksheets for this kit were made and followed in accordance with the manufacturer's recommendations.

We linked the assay results to each participant's demographic characteristics and their responses to the sexual risk behaviour checklist. Data regarding age, sex, sociodemographic status, behaviours of participants, and physical characteristics were all collected during interviews in the participants' households using PDAs. The data were downloaded into Microsoft Access databases and imported into Stata 16.0 (StataCorp, College Station, Texas 77,845 USA) statistical software, which was used for data analyses.

Overall, 7287 participants in the EMINI cohort were between the age of 15 and 49 years old. Participants meeting the inclusion criteria were randomized using Stata 16 after being stratified by age, sex, and HIV status. Stratification was necessary because otherwise, the number of HIV-positive participants would have been too low for meaningful comparisons.

Each participant was assigned a random number, and 23 participants were initially selected per stratum (overall $=23$ participants $\times 28$ strata $=644$ participants $). \quad A$ stratum (plural strata) refers to a subset of the population that is being sampled. Strata with fewer than 23 participants were filled from higher age strata with the same sex and HIV combination. For each stratum, 10 participants were also selected for replacement in case the selected initial samples could not be found (total number of replacements was 280). Responses from EMINI interviews were used to assess the sociodemographic characteristics of participants.

We performed all analyses in Stata. Univariate and multivariate associations of different factors with HSV-1 infection were analysed using Poisson regression with robust variance estimates.

\section{Results}

We randomly selected a total of 640 subjects from nine wards of the Mbeya region, and the sample has an equal distribution of sex and HIV status. The majority of the study population had completed a primary level of education $(58.4 \%)$, were farmers $(70.0 \%)$, were involved in seasonal activities (50.5\%), were married with one spouse 
(55.0\%), and were Christians (77.5\%). Some of the sociodemographic characteristics of these participants are shown in Table 1.

Six hundred and twenty-nine sera were tested for HSV-1; 18 sera were indeterminate, and in 11 participants, the volume of sera was insufficient to run the test. None of the sera with indeterminate results were retested. From 611 participant sera tested for herpes simplex virus type $1,51.2 \%$ were males, and $52.4 \%$ of sera came from HIV-negative individuals.

The overall seroprevalence of HSV-1 infection was 92.1\%, with males and females having a seroprevalence of 94.2 and $89.9 \%$, respectively. A total of $95.7 \%$ of HIVnegative and $83.2 \%$ of HIV-positive females were reactive to herpes simplex virus type 1 antibodies. These proportions were slightly lower than the seroprevalence of 96.9 and $91.6 \%$ among HIV-negative and HIV-positive males, respectively.

Table 1 Frequency distribution of sociodemographic characteristics $(n=640)$

\begin{tabular}{|c|c|c|}
\hline Demography & Frequency & Percent \\
\hline \multicolumn{3}{|l|}{ HIV status } \\
\hline Negative & 322 & 50.3 \\
\hline Positive & 318 & 49.7 \\
\hline \multicolumn{3}{|l|}{ Sex } \\
\hline Female & 319 & 49.8 \\
\hline Male & 321 & 50.2 \\
\hline \multicolumn{3}{|l|}{ Age group } \\
\hline $15-19$ & 77 & 12.0 \\
\hline $20-24$ & 83 & 13.0 \\
\hline $25-29$ & 106 & 16.5 \\
\hline $30-34$ & 101 & 15.8 \\
\hline $35-39$ & 90 & 14.1 \\
\hline $40-44$ & 90 & 14.1 \\
\hline $45-49$ & 93 & 14.5 \\
\hline \multicolumn{3}{|l|}{ Level of education } \\
\hline No formal education & 88 & 26.9 \\
\hline Completed primary & 374 & 58.4 \\
\hline After primary & 94 & 14.7 \\
\hline \multicolumn{3}{|l|}{ Marital status } \\
\hline Never married & 154 & 24.1 \\
\hline Married-one spouse & 352 & 55.0 \\
\hline Others & 134 & 20.9 \\
\hline \multicolumn{3}{|l|}{ Religion } \\
\hline No religion & 107 & 16.7 \\
\hline Christian & 496 & 77.5 \\
\hline Others & 36 & 5.8 \\
\hline
\end{tabular}

We stratified the study participants by HIV status, sex, and age to have enough participants in each stratum. Approximately $50 \%$ of study subjects were infected with HIV; the prevalence of HIV infection among the general population of Mbeya was 9.3\%. The unadjusted seroprevalence did not interfere with the analysis of the seroprevalence of HSV infections in HIV-infected and uninfected individuals; however, the unadjusted data did not represent the overall seroprevalence in the general population. After extrapolating the current results to the age, sex, and HIV status distribution of the EMINI study population, the seroprevalence estimate of herpes simplex virus type 1 in the general population was $95.0 \%$ ( $96.0 \%$ in males versus $94.0 \%$ in females).

A chi-square test of independence was performed to examine the relationship between sex and HSV-1 seropositivity. The relation between these variables was significant, $\mathrm{X}^{2}(1, N=611)=3.929, p=.047461$. Men were more likely than women to be HSV-1 positive (Table 2).

The correlation between HSV-1 and HIV status was tested using chi-square and $\mathrm{Z}$ score tests. A chi-square test of independence showed that there was a significant association between HSV-1 seropositivity and HIV status, $\mathrm{X}^{2}(1, N=611)=15.6482, p=.000076$; these findings were consistent with additional analyses, with a $\mathrm{Z}$ score of -3.9558 and a $p$-value of .00004 . The result suggests that either disease, namely, HIV, or HSV-1, would be protective against the other.

Poisson regression analysis with robust variance estimates showed that there was no significant change in the trend of seroprevalence of herpes simplex virus type 1 over age by HIV status.

To assess the univariate association of sex and HIV status with HSV-1 infection, Poisson regression analysis with robust variance estimates for stratified variables was used (Table 3). There was no significant difference in HSV infections between females and males. People with HIV were less likely to have HSV-1 infections. When we included the same variables in a multivariate model, the results revealed a $7 \%$ decrease in the seroprevalence of HSV-1 among HIV-positive patients.

\section{Discussion}

This study presents the first report of the seroprevalence of herpes simplex virus type 1 in the general population of Tanzania based on HIV status. The unadjusted seroprevalence of herpes simplex virus type 1 infections in this study population was $92.1 \%$, and the seroprevalence estimate for the general population was $95.0 \%$. The rate in our study is higher than the prevalence rates in the general population of the following countries: the United States of America, 67\% [17]; Israel, 59.8\% [18]; and Switzerland, 80\% [19]. The estimate from our study is, however, comparable to the general populations of some 
Table 2 Prevalence of herpes simplex virus type 1 by sex and HIV status

\begin{tabular}{llll}
\hline & Male (Expected total) $\left[X^{2}\right]$ & Female (Expected total) $\left[X^{2}\right]$ & \\
\hline HSV-1 & & & Total \\
Positive & $295(288.41)[0.15]$ & $268(274.59)[0.16]$ & $30(23.41)[1.85]$ \\
Negative & $18(24.59)[1.77]$ & 298 \\
& 313 & HIV Negative & 483 \\
& HIV Positive & $308(294.86)[0.59]$ & 611 \\
Positive & $255(268.14)[0.64]$ & $12(25.14)[6.87]$ & 563 \\
Negative & $36(22.86)[7.55]$ & 320 \\
& 291 & & 48 \\
\hline
\end{tabular}

The chi-square statistic is 3.929 . The $p$-value is .047461 . This result is significant at $p<.05$

regions in Syria [20], rural Uganda (91.2\%) [21], and the urban region of Tanzania (92\%) [22].

In contrast to other studies where the seroprevalence of HSV-1 was significantly higher in females [23-25], this study shows that men are more often infected than women. However, this association was no longer significant after adjusting for other factors in the multivariate model $($ PR 1.04, $p$-value $=.110)$.

Surprisingly, the present study shows a lower seroprevalence of herpes simplex virus type 1 infection among HIV-positive individuals compared to HIVnegative individuals ( $87.6 \%$ vs. $96.3 \%)$. In univariate and multivariate analyses, HIV positivity was associated with lower HSV-1 seropositivity.

This is the first study to report the low seroprevalence of HSV-1 in HIV-infected individuals. These findings were derived from a seroprevalence study, and henceforth the presence of genital herpes by HSV-1 was not assessed. The finding could also have been confounded by other dynamics such as age at sexual debut, behavioral factors like condom use and herpes simplex type 2 infections; and therefore, this finding in this study design should, consequently, be interpreted with caution.

Do HIV positive individuals receive more information about condom use than non-positive, and henceforth they have a better chance of protection against sexually transmitted infections, such as HSV-1? Some studies in sub-Saharan Africa have already described low condom use among individuals on antiretroviral drugs [2, 3]. While most HSV-1 infections are acquired in childhood but changes in HSV-1 epidemiology have been witnessed showing acquisition in later age [26]. Another study has also reported that HSV-1 infection is not transmitted sexually in HIVinfected individuals [27]. Meanwhile, from our research group, in the same participants' sera, the seroprevalence of HSV-2 IgG was higher in HIV-positive individuals (unpublished observation).

Table 3 Univariate and multivariate association of various factors with HSV-1 infection

\begin{tabular}{|c|c|c|c|c|c|}
\hline$\underline{\text { Variable }}$ & Stratum & Number in stratum & Prevalence ratio & $95 \% \mathrm{Cl}$ & $P$-value \\
\hline \multicolumn{6}{|c|}{ Univariate } \\
\hline \multicolumn{6}{|l|}{ Sex } \\
\hline & Female* & 298 & 1 & - & - \\
\hline & Male & 313 & 1.05 & (1.00 to 1.10$)$ & 0.050 \\
\hline \multicolumn{6}{|c|}{ HIV status } \\
\hline & Negative $^{*}$ & 320 & 1 & - & - \\
\hline & Positive & 291 & 0.91 & (0.87 to 0.96$)$ & $<0.001$ \\
\hline \multicolumn{6}{|c|}{ Multivariate } \\
\hline \multicolumn{6}{|l|}{ Sex } \\
\hline & Female* & 298 & 1 & - & - \\
\hline & Male & 313 & 1.04 & (0.99 to 1.10$)$ & 0.110 \\
\hline \multicolumn{6}{|l|}{ HIV status } \\
\hline & Negative* & 320 & 1 & - & - \\
\hline & Positive & 291 & 0.93 & (0.89 to 0.98$)$ & 0.004 \\
\hline
\end{tabular}

Results of Poisson regression with robust variance estimates for stratified variables. Univariate and multivariate models for sex, age, and HIV status, all other variables adjusted for sex, age, and HIV status 
There is a paucity of epidemiological studies that describe the interaction of HSV-1 and HIV. The present findings support the observed negative in vitro interaction between HSV-1 and HIV. Calistri et al. [28] used the CD4 human lymphoblastoid cell line CEM that was infected chronically by HSV-1, $\mathrm{CEM}_{\mathrm{HSV}}$, and superinfected the cells with HIV-1. They found that HIV-1 growth was inhibited, probably due to HSV-1 failing to induce HIV-1 gene expression through the transactivation of the long terminal repeat (LTR).

Correspondingly, one more study has found that membrane-bound HSV-1 glycoprotein D is required for inhibiting the release of infectious HIV-1 [29]. Likewise, Polpitiya et al. found HSV-1 proteins, such as glycoprotein M, US3, and UL24, potently restricted the replication of HIV-1 and also prevented the incorporation of the HIV-1 gp120/gp41 into virus particles [30].

\section{Conclusions}

The seroprevalence of HSV-1 in this population was high. People living with HIV were less likely to be HSV1 positive. The current study design is susceptible to many confounding factors, and it is difficult to determine the causal association. Further prospective studies are necessary to conclude a causal relationship.

\section{Abbreviations}

HIV: Human Immunodeficiency Virus; AIDS: Acquired Immune Deficiency Syndrome; HSV-1: Herpes Simplex Virus Type 1; EU: European Union; EMINI: Establishment of the Infrastructure to Evaluate and Monitor the Impact of New Interventions; ELISA: Enzyme-Linked Immunosorbent Assay; gG1: Glycoprotein G 1; NIMR: National Institute for Medical Research; MMRC: Mbeya Medical Research Center; PDAs: Personal Digital Assistants; TX: Texas; MMReC: Mbeya Medical Research and Ethics Committee;

Cl: Confidence Interval; CEM: Contagious Equine Metritis

\section{Acknowledgements}

Not applicable.

\section{Study limitations}

This study shows that both types of HSV-1 infections are less common in HIV-infected individuals. Limited by its cross-sectional design, the analysis of possible risk factors suggests that inferences from its findings should be made cautiously regarding the possible observed association.

\section{Strength of the study}

The strength of this study is the use of statistical methods tailored to the high prevalence of herpes simplex virus type 1 infection. The use of Poisson regression models with robust variance estimates allows for the direct estimation of prevalence ratios, which are more interpretable than odds ratios in high prevalence situations [31].

\section{Authors' contributions}

$\mathrm{HMI}$ and AAN designed, analysed and interpreted the research findings. $\mathrm{HMI}$ and AAN performed the serological testing and were major contributors in writing the manuscript. HMI, GRM, GFM, DDN and NEN drafted the work and substantively revised it. All authors read and approved the final manuscript.

\section{Funding}

This work was supported by Mbeya Zonal Referral Hospital and NIMR-MMRC.

\section{Availability of data and materials}

The datasets generated during and/or analysed during the current study are available from the corresponding author upon reasonable request.

\section{Ethics approval and consent to participate}

We sought ethical clearance to use archived participants' data and serum from the Muhimbili University of Health and Allied Sciences and Mbeya Medical Research and Ethics Committees (MMReC). We observed confidentiality, and no unauthorized persons had access to the collected data. Each subject was assigned a study identification number that was not linked to individual names.

\section{Consent for publication}

Not applicable.

\section{Competing interests}

The authors declare that they have no competing interests.

\section{Author details}

${ }^{1}$ Mbeya Zonal Referral Hospital, Mbeya, Tanzania. ${ }^{2}$ University of Dar es Salaam Mbeya College of Health and Allied Sciences, Mbeya, Tanzania. ${ }^{3}$ Mbeya Regional Referral Hospital, Mbeya, Tanzania. ${ }^{4}$ NIMR-Mbeya Medical Research Center, Mbeya, Tanzania.

Received: 22 November 2019 Accepted: 27 July 2020

Published online: 05 August 2020

\section{References}

1. FINAL_THIS-2016-2017_Final-Report_06.21.19_for-web_TS.pdf [Internet]. [cited 2019 Sep 9]. Available from: https://phia.icap.columbia.edu/wpcontent/uploads/2019/06/FINAL_THIS-2016-2017_Final-Report_06.21.19_ for-web_TS.pdf.

2. Dodds JP. Increase in high risk sexual behaviour among homosexual men, London 1996-8: cross sectional, questionnaire study. BM. 2000;320(7248):1510-1.

3. Do AN, Hanson DL, Dworkin MS, Jones JL. Risk factors for and trends in gonorrhea incidence among persons infected with HIV in the United States. AIDS. 2001;15(9):1149-55.

4. Bouhnik A-D. Highly active antiretroviral treatment does not increase sexual risk behaviour among French HIV infected injecting drug users. J Epidemiol Community Health. 2002;56(5):349-53.

5. Ayoub HH, Chemaitelly H, Abu-Raddad LJ. Characterizing the transitioning epidemiology of herpes simplex virus type 1 in the USA: model-based predictions. BMC Med. 2019:17(1):57.

6. Pereira VSS, Moizeis RNC, Fernandes TAAM, Araújo JMG, Meissner RV, Fernandes JV. Herpes simplex virus type 1 is the main cause of genital herpes in women of Natal, Brazil. Eur J Obstet Gynecol Reprod Biol. 2012 Apr:161(2):190-3.

7. Lafferty WE, Downey L, Celum C, Wald A. Herpes simplex virus type 1 as a cause of genital herpes: impact on surveillance and prevention. J Infect Dis. 2000;181(4):1454-7.

8. Lowhagen G-B. First episodes of genital herpes in a Swedish STD population: a study of epidemiology and transmission by the use of herpes simplex virus (HSV) typing and specific serology. Sex Transm Infect. 2000 Jun 1:76(3):179-82.

9. Ross JD, Smith IW, Elton RA. The epidemiology of herpes simplex types 1 and 2 infection of the genital tract in Edinburgh 1978-1991. Sex Transm Infect. 1993 Oct 1;69(5):381-3.

10. Mertz GJ, Rosenthal SL, Stanberry LR. Is Herpes Simplex Virus Type 1 (HSV-1) Now More Common than HSV-2 in First Episodes of Genital Herpes? Sex Transm Dis. 2003:30(10):801-2.

11. Freeman EE, Weiss HA, Glynn JR, Cross PL, Whitworth JA, Hayes RJ. Herpes simplex virus 2 infection increases HIV acquisition in men and women: systematic review and meta-analysis of longitudinal studies. AIDS. 2006; 20(1):73-83.

12. Abu-Raddad $\amalg$, Magaret AS, Celum C, Wald A, Longini IM, Self SG, et al. Genital Herpes Has Played a More Important Role than Any Other Sexually Transmitted Infection in Driving HIV Prevalence in Africa. Bangsberg DR, editor. PLoS ONE. 2008;3(5):e2230.

13. Sobngwi-Tambekou J, Taljaard D, Lissouba P, Zarca K, Puren A, Lagarde E, et al. Effect of HSV-2 Serostatus on acquisition of HIV by young men: results 
of a longitudinal study in Orange farm, South Africa. J Infect Dis. 2009; 199(7):958-64.

14. Wald A. Herpes simplex virus type 2 transmission: risk factors and virus shedding. Herpes I IHMF. 2004;11(Suppl 3):130A-7A.

15. Schiffer JT, Gottlieb SL. Biologic interactions between HSV-2 and HIV-1 and possible implications for HSV vaccine development. Vaccine. 2019 Nov; 37(50):7363-71.

16. Zuckerman R, Manji K, Matee M, Naburi H, Bisimba J, Martinez R, et al. HSV oropharyngeal shedding among HIV-infected children in Tanzania. Int J STD AIDS. 2015;26(7):456-61.

17. ACOG practice bulletin: Clinical management guidelines for obstetriciangynecologists, number 57, November 2004. Gynecologic herpes simplex virus i... - PubMed - NCBI [Internet]. [cited 2019 Oct 1]. Available from: https://www.ncbi.nlm.nih.gov/pubmed/15516420.

18. Davidovici BB, Green M, Marouni MJ, Bassal R, Pimenta JM, Cohen D. Seroprevalence of herpes simplex virus 1 and 2 and correlates of infection in Israel. J Inf Secur. 2006;52(5):367-73.

19. Bünzli D, Wietlisbach V, Barazzoni F, Sahli R, Meylan PR. Seroepidemiology of Herpes Simplex virus type 1 and 2 in Western and Southern Switzerland in adults aged 25-74 in 1992-93 : a population-based study. BMC Infect Dis. 2004;4(1):10.

20. Ibrahim Al, Kouwatli KM, Obeid MT. Frequency of herpes simplex virus in Syria based on type-specific serological assay. Saudi Med J. 2000;21(4):35560.

21. Wagner HU, Van Dyck E, Roggen E, Nunn AJ, Kamali A, Schmid DS, et al. Seroprevalence and incidence of sexually transmitted diseases in a rural Ugandan population. Int J STD AIDS. 1994;5(5):332-7.

22. Kasubi MJ, Nilsen A, Marsden HS, Bergstrom T, Langeland N, Haarr L. Prevalence of antibodies against herpes simplex virus types 1 and 2 in children and young people in an urban region in Tanzania. J Clin Microbiol. 2006 Aug 1;44(8):2801-7.

23. Cunningham AL, Taylor R, Taylor J, Marks C, Shaw J, Mindel A. Prevalence of infection with herpes simplex virus types 1 and 2 in Australia: a nationwide population based survey. Sex Transm Infect. 2006 Apr 1;82(2):164-8.

24. Malkin J-E. Seroprevalence of HSV-1 and HSV-2 infection in the general French population. Sex Transm Infect. 2002;78(3):201-3.

25. Bradley H, Markowitz LE, Gibson T, McQuillan GM. Seroprevalence of herpes simplex virus types 1 and 2--United States, 1999-2010. J Infect Dis. 2014 Feb 1;209(3):325-33

26. Manavi K, Mcmillan A, Ogilvie M. Herpes simplex virus type 1 remains the principal cause of initial Anogenital herpes in Edinburgh, Scotland. Sex Transm Dis. 2004 May;31(5):322-4.

27. van Benthem BHB. Prevalence and risk factors of HSV-1 and HSV-2 antibodies in European HIV infected women. Sex Transm Infect. 2001;77(2): $120-4$.

28. Calistri A, Parolin C, Palù G. Herpes simplex virus type 1 can either suppress or enhance human immunodeficiency virus type 1 replication in CD4positive T lymphocytes: HIV and HSV-1 interactions in T lymphocytes. J Med Virol. 2003;70(1):163-70.

29. Polpitiya Arachchige S, Henke W, Kalamvoki M, Stephens EB. Analysis of herpes simplex type $1 \mathrm{gB}, \mathrm{gD}$, and $\mathrm{gH} / \mathrm{gL}$ on production of infectious HIV-1: HSV-1 gD restricts HIV-1 by exclusion of HIV-1 Env from maturing viral particles. Retrovirology. 2019 Dec;16(1):9.

30. Polpitiya Arachchige S, Henke W, Pramanik A, Kalamvoki M, Stephens EB. Analysis of select herpes simplex virus 1 (HSV-1) proteins for restriction of human immunodeficiency virus type 1 (HIV-1): HSV-1 gM protein potently restricts HIV-1 by preventing intracellular transport and processing of Env gp160. Sandri-Goldin RM, editor. J Virol. 2017;92(2):e01476-17.

31. Spiegelman D, Easy SAS. Calculations for risk or prevalence ratios and differences. Am J Epidemiol. 2005;162(3):199-200.

\section{Publisher's Note}

Springer Nature remains neutral with regard to jurisdictional claims in published maps and institutional affiliations.

Ready to submit your research? Choose BMC and benefit from:

- fast, convenient online submission

- thorough peer review by experienced researchers in your field

- rapid publication on acceptance

- support for research data, including large and complex data types

- gold Open Access which fosters wider collaboration and increased citations

- maximum visibility for your research: over $100 \mathrm{M}$ website views per year

At BMC, research is always in progress.

Learn more biomedcentral.com/submissions 